Available online at https://journal.rescollacomm.com/index.php/ijrcs/index

International Journal of Research in Community Service

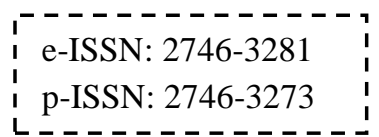

Vol. 2, No. 1, pp. 18-23, 2021

\title{
Production Development Strategy on Corn (Zea Mays) Commodity in Banten Province Using Process Hierarchy Analysis Method
}

\author{
Ahmad Alfarizy $^{1 *}$, Mohamad Arief Setiawan ${ }^{2}$ and Kalfin ${ }^{3}$ \\ ${ }^{l}$ Department of Agribusiness, \\ Faculty of Agriculture, University of Sultan Ageng Tirtayasa, Indonesia \\ ${ }^{2}$ Faculty of Agriculture, Padjadjaran University, Indonesia \\ ${ }_{3}^{3}$ Doctor Program of Mathematics,
}

Faculty of Mathematics and Natural Sciences, Universitas Padjadjaran, Indonesia

Corresponding author e-mail address: ariefs868@gmail.com

\begin{abstract}
The increased rate of maize production in Indonesia is relatively slow, on the other hand the need for corn as raw material for the food industry and faster food improvement. Still, demand for maize for direct consumption during the economic crisis also increased. This study aims to identify corn development strategy in Banten Province and formulate priority scale efforts for corn commodity development strategy in Banten province. The type of this research is qualitative with descriptive approach, with the research location taken intentionally (purposive). The in Banten Province, then prioritize the strategy to improve and expand the marketing network in the form of fruit and corn processing products (corn kernels) through the program of local superior product introduction to outsiders of Banten Province. The priority of the fifth development strategy is to increase cooperation between farmers, processing industries, and traders with the government. Sampling technique used purposive sampling method with 52 respondents consisting of farmer, processing industry, trader, and government. Data analysis using Analytic Hierarchy Process and Focus Group Discursion. The result of this research is the alternative development strategy of 25 strategies which are all obtained through Focus Group Discussions and Analytic Hierarchy Process method, then get the strategy priority scale, the priority strategy to improve corn cultivation technique in Banten Province, then priority of strategy improvement of facilities and infrastructure. The priority of further development strategy is to improve the quality and quantity of maize.
\end{abstract}

Keywords: Development Strategy, Analytic Hierarchy Process, Priority Scale, Corn

\section{Introduction}

Agriculture is the basis of the Indonesian economy. The majority of Indonesia's population, most of whom live in rural areas, still rely on the agricultural sector for their livelihoods (Kalfin et al., 2021; Maharani et al., 2021). In addition to providing food for the population and absorbing labor, the agricultural sector is also a supplier of raw materials for the industrial sector and a source of foreign exchange earners (Fkun and Pareira, 2021; Inopianti et al., 2021). Agricultural development is an integral part of national development, therefore the vision and mission of agricultural development is formulated 
within the framework and refers to the achievement of the vision and mission of national development (Situmorang, 2020; Gracino et al., 2021; Ula et al., 2021).

Banten Province is one of the provinces in Indonesia that is trying to develop the regional economy. Banten Province also has the potential of the agricultural sector that deserves to be developed (Fakhri et al., 2014; Susilowati et al., 2019; Syafrizal, 2019). Regional development of Banten Province is supported by several economic sectors, namely the agricultural sector; mining and quarrying sector; industrial sector; electricity, gas and clean water sectors; construction and building sector; trade sector; transportation sector; the banking sector and other financial institutions; information and communication sector; real estate sector; government administration sector and services sector. Although the agricultural sector in Banten Province is not the leading sector, the agricultural sector is a sector that contributes quite a lot from 2012 to 2015 (BPS Banten Province, 2016).

Corn is the main raw material in the manufacture of feed. The proportion of corn used, especially in the manufacture of broiler feed, reaches $51.4 \%$ of the total raw materials used. The rate of increase in corn production in Indonesia is still relatively slow, on the other hand the demand for corn as a raw material for the feed industry and food industry has increased more rapidly. Even the demand for corn for direct consumption during the economic crisis also tends to increase (Mawaddah et al., 2021; Hikmawan, 2020; Sutisna, 2019; Budiawati, 2021).

Based on the description of the problems mentioned above, this research is interested in how alternative strategies for developing maize are and efforts to prioritize the development of maize commodities in Banten Province. This research needs to be done to find out the extent of the development level of corn commodities in the community. From the research results, it is expected to increase the development of corn commodities. In addition, it can be a reference for local governments in making policies for developing corn commodities in the province of Banten.

\section{Research methodology}

The basic method used in this research is descriptive analysis method. Descriptive analysis method is a problem solving procedure that is investigated by describing the current state of the object or subject based on the facts that appear as they are and then analyzed (Shugar, 2020). The method of taking the area is done purposively, namely taking this area by considering the reasons known from the research. The research area taken is the province of Banten. The types and sources of data used in this study are primary data and secondary data.

The analytical tools used in this study are as follows:

\section{1) Analysis of Alternative Strategies Using FGD (Focus Group Discussion)}

To determine how alternative strategies will be used in the development of corn commodities in the study, a Focus Group Discussion will be used, where researchers will hold discussions as well as interviews with relevant parties who are influential in determining the strategy for developing corn commodities in Banten Province, then the results of this FGD will used as an alternative in determining the strategy for developing corn commodities in Banten Province.

2) Analysis of priority scale efforts for corn commodity development strategy in Banten Province using Process Hierarchy Analysis (AHP).

The stages in the analysis of priority scale efforts for the corn commodity development strategy of Banten Province using Process Hierarchy Analysis are arranged as follows:
a) Criteria and Alternative Assessment
b) Determining the priority of elements
c) Add up the values of each column in the matrix
d) Add up the values of each row and divide by the number of elements to get the average value
e) Doing the sum on each row,
f) Calculating the Consistency Index (CI) with the formula: 
$\mathrm{CI}=(1 \max ) / \mathrm{n}$, for $\mathrm{n}=$ number of elements

g) Calculating the Consistency Ratio (CR) with the formula:

$\mathrm{CR}=\mathrm{CI} / \mathrm{IR}$, with $\mathrm{IR}=$ Index Random Consistency

h) Check hierarchy consistency. If the CR value is more than $10 \%$, then the judgment data assessment must be corrected, but if the CR is less or equal to zero (0), then the calculation results can be declared correct.

\section{Results and Discussion}

\subsection{Results of FGD Analysis}

Hierarchy determination is carried out by researchers with the main stages of determining the main objectives, criteria and alternatives. Determination of the criteria is done when the researchers have conducted discussions / FGD with parties who are influential in the development of corn production. Where the FGD aims to become a means of discussion for various stakeholders both from the center and from the regions in order to produce effective policy recommendations for maize development in Banten province and at the national level. Based on the results of the analysis of the criteria in the preparation of the hierarchy, it is divided into four levels. For level 1, it relates to cultivation techniques, post-harvest planting training, use of fertilizers, irrigation channels, and collaboration between farmers and institutions. Level 2 relates to the procurement and distribution of fertilizer subsidies, seed subsidies, farmer partnerships and extension activities. Level 3 relates to the supply of corn stocks, imports of corn, the corn processing industry, corn self-sufficiency, and improving the economy and welfare of farmers. Level 4, discusses the corn marketing network, corn quality and quantity, supporting organizations, corn agro-industry and the added value of processed corn products.

\subsection{Prioritization and Consistency}

Assessment of the degree of importance of the hierarchy level will show the results that the priority is very influential on the development of corn commodities in Banten Province. The prioritization and consistency can be seen in Table 1 .

Table 1. Prioritization and Consistency

\begin{tabular}{|c|c|c|c|c|}
\hline Hierarchy & Quantity per Line & Priority & Results & \\
\hline A1 & 1.8791 & 0.0751 & 2.2075 & \\
\hline $\mathrm{A} 2$ & 1.3932 & 0.0557 & 1.6577 & 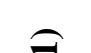 \\
\hline A3 & 1.6553 & 0.0662 & 2.0146 & z' \\
\hline A4 & 0.8824 & 0.0352 & 1.0490 & $\stackrel{5}{2}$ \\
\hline A5 & 0.6773 & 0.0270 & 0.8157 & $Z_{y}$ \\
\hline A6 & 1.1743 & 0.0469 & 1.4621 & שֶ \\
\hline A7 & 0.9582 & 0.0383 & 1.0917 & $\sum$ \\
\hline A8 & 1.2951 & 0.0518 & 1.5645 & II \\
\hline A9 & 0.8188 & 0.0327 & 0.9664 & U \\
\hline A10 & 0.8477 & 0.0339 & 0.9748 & \\
\hline B1 & 1.2951 & 0.0518 & 1.5443 & \\
\hline B2 & 1.3240 & 0.0529 & 1.5551 & $\stackrel{1}{\Xi}$ \\
\hline B3 & 0.9502 & 0.0380 & 1.0744 & $\%$ \\
\hline B4 & 0.8207 & 0.0328 & 0.9702 & $\widehat{\pi}$ \\
\hline B5 & 1.1370 & 0.0454 & 1.3195 & $\mathscr{u}$ \\
\hline $\mathrm{C} 1$ & 0.4399 & 0.0175 & 0.4947 & \\
\hline
\end{tabular}




\begin{tabular}{ccccc}
\cline { 3 - 5 } C2 & 0.3852 & 0.0154 & 0.4396 & \\
C3 & 0.6841 & 0.0273 & 0.7922 & \\
C4 & 0.4249 & 0.0169 & 0.4928 & \\
C5 & 1.0884 & 0.0435 & 1.2486 & \\
D1 & 1.5531 & 0.0621 & 1.8216 & 光 \\
D2 & 1.5679 & 0.0627 & 1.8408 & ป \\
D3 & 0.6145 & 0.0245 & 0.6993 & U \\
D4 & 0.7925 & 0.0317 & 0.9261 & \\
D5 & 0.3399 & 135 & 0.3998 & \\
\hline Amount & $\mathbf{2 5}$ & $\mathbf{1}$ & $\mathbf{2 9 . 4 2 4 2}$ & \\
\hline Amax & & & & $\mathbf{2 9 . 2 9 7 8 1}$ \\
CI & & & & $\mathbf{0 . 1 7 9 0 7 5}$ \\
CR & & & & $\mathbf{0 . 0 9 8 3 0 7}$
\end{tabular}

\subsection{Hierarchy}

Based on the results of field analysis, it can be given the flow of corn commodity development in Banten province based on Figure 1.

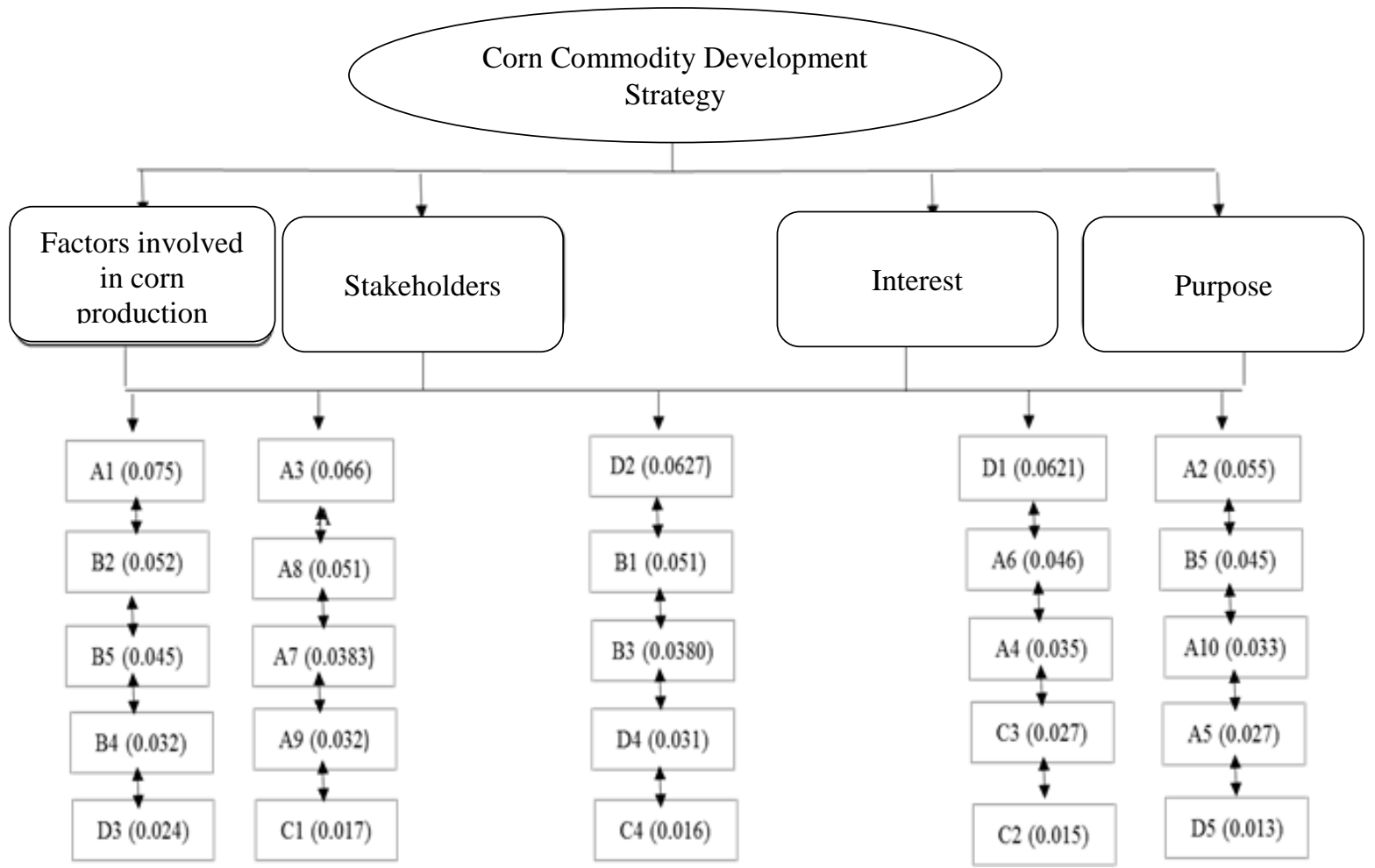

Figure 1. Corn Commodity Development Strategy 


\section{Conclussion}

Based on the research results, there are 25 alternative strategies in the development of corn commodities in Banten Province. Of the 25 strategies, there are five priority strategies including, the priority strategy for increasing cooperation between farmers, processing industries, and traders with the government (Related Office), then strategies for improving advice and infrastructure in terms of road access and market access. The priority of the next development strategy is to improve the quality and quantity of corn in Banten Province, then the priority of the strategy is to improve and expand the marketing network both in the form of fruit and processed corn products (corn chips) through the introduction of local superior products to parties outside the Banten Province, then improving techniques corn commodity cultivation in Banten Province.

\section{References}

BPS Provinsi Banten. 2016. Banten dalam Angka 2016. Badan Pusat Statistik Provinsi Banten.

Budiawati, Y., Islami, R. Z., Perdana, T., \& Natawidjaja, R. S. (2021, March). Posible Use of Food Security and Vulnerability Atlas (Fsva) to Detect Problem on Poverty and Stunting, The Case of Banten Province. In IOP Conference Series: Earth and Environmental Science (Vol. 715, No. 1, p. 012008). IOP Publishing.

Departemen Pertanian. 2005.Prospek dan Arah Pengembangan Agribisnis Jagung. Badan Penelitian dan Pengembangan Pertanian. Deptan.

Fakhri, M., Aditya, M., \& Pradana, M. (2014). Factor analysis of work motivation using Maslow's hierarchy of needs: Case study on civil servants at Banten Province's Office of Agriculture and Livestock. In International Conference on Emerging Trends in Academic Research (pp. 258-274).

Fkun, E., \& Pareira, M. S. (2021, June). Strengthening the Agriculture Sector as a Locomotive of Economic Development in Border Areas Indonesia-Timor Leste (Study TTU Regency). In 2nd Annual Conference on blended learning, educational technology and Innovation (ACBLETI 2020) (pp. 93-97). Atlantis Press.

Hikmawan, M. D., Hamid, A., Nurrohman, B., Ramadhan, G., \& Mayrudin, Y. M. A. (2020). Collaborative Governance Model on Agricultural Business in Banten, Indonesia. Jurnal Transformative, 6(2), 176-201.

Inopianti, N., Munibah, K., \& Purwanto, M. Y. J. (2021). Implementation of Sustainable Food Agricultural Land Protection Policy in Sukabumi City, West Java, Indonesia. International Journal of Business, Economics, and Social Development, 2(3), 107-112.

Gracino, M. A., Priyanti, E., \& Azijah, D. N. (2021). Collaborative Governance: Re-Enactment Share Understanding in the Process of Agricultural Food Management in Karawang Regency. International Journal of Business, Economics, and Social Development, 2(1), 18-23.

Kalfin, Sukono, Supian S., Mamat, M., Muljana, F., \& Bon, A. T. (2021)Analysis of Agropolitan Area Planning Based on Natural Disaster Mitigation in West Muna Regency, Southeast Sulawesi, Indonesia. Proceedings of the International Conference on Industrial Engineering and Operations Management, Sao Paulo, Brazil, pp. $3592-3601$.

Maharani, M. D. D., Amin, H. F., \& Triana, Y. S. (2021). Application of Artificial Intelligence in Modern Ecology for Detecting Plant Pests and Animal Diseases. International Journal of Quantitative Research and Modeling, 2(2), 83-90. 
Mawaddah, U., Virganta, A. L., Adinda, N., Ginting, D. Z. B., Aulia, C. F., \& Hasibuan, I. Eskalasi (2021) Nilai Ekonomi Jagung Melalui Kreasi Olahan Makanan di Desa Kolam Kecamatan Percut Sei Tuan Kabupaten Deli Serdang. Jurnal Bunga Rampai Usia Emas, 7(2), 56-62.

Shugar, G. W. (2020, September). A method of descriptive analysis of child activity in the period of language acquisition. In Colloquium Paedolinguisticum (pp. 242-253). De Gruyter Mouton.

Situmorang, D. (2020). Perubahan Pemberian Kompensasi Terhadap Pekerja Di Sumatera Utara Pada Sektor Perkebunan Kelapa Sawit. Jurnal Ilmiah Ekonomi dan Bisnis Triangle, 1(2), 429-437.

Susilowati, M. H. D., Wibowo, A., \& Susiloningtyas, D. (2019, August). Spatial pattern of drought disaster area and types of agriculture plant in Lebak Regency, Banten Province. In IOP Conference Series: Earth and Environmental Science (Vol. 311, No. 1, p. 012022). IOP Publishing.

Sutisna, T. (2019, November). The local farming system based on custom and tradition to achieve sustainable agriculture in Baduy indigenous community. In IOP Conference Series: Earth and Environmental Science (Vol. 383, No. 1, p. 012032). IOP Publishing.

Syafrizal, S. (2019). Climate-based Land Optimization to Increase Agricultural Production in Banten Province. The Journal of Research on the Lepidoptera, 50(3), 356-364.

Ula, S., Eng, M., Susilo, S., Listijorini, E., Irawan, R., Sambas, A., \& Assidiq, A. T. (2021). Spraying Agricultural Crops Based on Internet of Things (IoT). FLYWHEEL: Jurnal Teknik Mesin Untirta, 20-25. 